ERRATA

To the Paper:

\title{
SUBSTOICHIOMETRIC ISOTOPE DILUTION ANALYSIS OF ARSENIC IN BIOLOGICAL AND ENVIRONMENTAL STANDARD REFERENCE MATERIALS BY SOLVENT EXTRACTION USING TOLUENE-3,4-DITHIOL IN BENZENE
}

\author{
N. L. CHUTKE, Ms. M. N. AMBULKAR, R. G. WEGINWAR, A. N. GARG* \\ Department of Chemistry, Nagpur University, Nagpur-440010 (India)
}

appeared in the

Journal of Radioanalytical and Nuclear Chemistry, Articles, Vol. 185, No. 1 (1994) 145-156.

The followings should be corrected:

Page (line) Existing Correct

145 , second para,

line 1

homeopathic homoeopathic

151, Table 1 ,

line 8 , column 3

64

264

153, Table 4,

line 12 , column $4 \quad 0.06 \quad 6.00$

line 19 , column $2 \quad 5.43 \quad 0.54$

$\begin{array}{lll}\text { column } 4 & 23.0 \% & 23.0\end{array}$

On page 155, Ref. (25) is missing. It is as follows:

25. J. RUZICKA, J. STARÝ, Substoichiometric Radiochemical Analysis, Pergamon Press, London, 1968, p. 6.

After this all the references from 25 to 39 should be renumbered as 26 to 40 . 